\title{
SOUTH AFRICA'S QUIXOTIC HERO AND HIS NOBLE QUEST - CONSTITUTIONAL COURT JUSTICE ALBIE SACHS AND THE DREAM OF A RAINBOW NATION
}

\author{
Stephen Peté \\ BA LLB LLM MPhil \\ Associate Professor, Faculty of Law \\ University of KwaZulu-Natal, Durban \\ Attorney of the High Court of South Africa
}

\section{SUMMARY}

Albie Sachs has always been clear-sighted in his vision of a rainbow nation at the southern tip of Africa, characterised by tolerance and mutual respect among and between its citizens. Using the well-known story of Don Quixote de la Mancha as a metaphor, this article sets out to chart the "quest" undertaken by Albie Sachs in pursuit of his noble dream. It traces a number of important personal and political transitions that he has made along the way, from his initial emphasis on solidarity and revolutionary struggle, to his later focus on issues of diversity and tolerance. The article touches briefly on aspects of Albie Sachs's inspiring dignity jurisprudence which it applauds, but then poses the question as to whether or not his views represent real hope to a country which, a decade and a half after the end of apartheid, remains fractured and traumatized.

In a book published in 2004, approximately one decade after the demise of apartheid, former South African Constitutional Court Justice Albie Sachs tells of visiting Belgium for the purpose of raising funds for the South African Constitutional Court's Architectural Artworks. This particular plea for funds was rejected and he describes his reaction to this as follows:

'It is so tiring to be a supplicant, despite the fact that everybody 'really loves' the cause. Oh well, even if like my hero Don Quixote I find myself knocked off my horse and having to get up out of the dust once again, I have at least done something for South Africa, strengthening the idea that we are a cultivated people serious about democracy, human rights and culture." 
This passing reference by Sachs to the hero of Miguel de Cervantes' wellknown work Don Quixote de la Mancha provides an interesting starting point for an analysis of the path travelled by Sachs, from fiery anti-apartheid revolutionary to one of South Africa's most respected jurists. The character of Don Quixote also provides an interesting point of reference in assessing the impact of Sachs and certain of his central ideas on South Africa's developing democracy.

Don Quixote is one of the best-loved characters in the Western literary tradition. The stories of his adventures date back to the start of the seventeenth century, with part one of Don Quixote de la Mancha being published in 1605 and part two appearing ten years later in 1615. The Oxford Dictionary of English describes the work as "a satire on chivalric romances that greatly influenced the development of the novel", and states that the character of Don Quixote "is typified by a romantic vision and naïve, unworldly idealism". ${ }^{2}$ Such has been the impact of Cervantes' work, and so well-loved is its main character, that it has resulted in the development of the English adjective "quixotic", which is defined as "extremely idealistic; unrealistic and impractical ..." Like Don Quixote, Sachs is certainly well-loved, but is it legitimate to describe him as a "quixotic hero", as the title of this article would seem to suggest?

It is contended in this article that there is indeed a sense in which Sachs may be characterised as a chivalrous knight errant, tilting at windmills in pursuit of a romantic (and, perhaps, ultimately hopeless) ideal. His quest, or perhaps we should call it his noble dream, is of a Rainbow Nation at the southern tip of Africa. The relevance and urgency of his quest, it is suggested, is that even now, fifteen years after the dawn of democracy, there exists still within each South African, a world of sorrow, a world of pain, a world of anger, and a world of regret. This dragon of tears and rage, of fear and hate, is stalking the country and threatening the newly established South African democracy. It is submitted that the South African people are in dire need of a noble knight to help slay this dragon and give them hope. A central question to be addressed in this article is whether or not the vision of a rainbow nation put forward by Sachs in his judgments and other writings is able to provide South Africa and its people with the necessary hope, or whether his quest is, in fact, hopelessly idealistic and doomed to failure.

The article begins by providing a few brief biographical details in respect of Sachs, in order to place the career of this remarkable South African jurist into historical context. In addition to the factual details about his life and career, however, an effort is made to capture something of the humanity of the man. Snapshots of his thinking on a diverse range of issues, including spirituality, love, women, and art are provided. By doing so, it is hoped that the lines of association between the central character of this article, and the hero of Cervantes' famous novel will be illustrated and illuminated.

\footnotetext{
2 The Oxford Dictionary of English 2ed (2003). See definitions of the terms: "Cervantes" and "Don Quixote".

3 The Oxford Dictionary of English 2ed (2003). See definition of the term: "quixotic".
} 
Following the above, the article focuses on a specific issue which has been of central concern to Sachs throughout his career, and which is of central concern to South Africans in their efforts to establish a "rainbow nation". This is the issue of tolerance and diversity within a fractured and traumatised country; the issue of what precisely it means to be a "South African" within a newly democratic South Africa. In a paper written in 1990, as the country began to emerge from apartheid, Sachs asked his comrades in the ANC the following question:

"Can we say that we have begun to grasp the full dimensions of the new country and new people that is struggling to give birth to itself, or are we still trapped in the multiple ghettoes of the apartheid imagination?"4

Over the years, as South Africa emerged from apartheid and established itself as a democratic country, Sachs has himself attempted to answer to this question. This article focuses particularly on aspects of his sensitive and inspiring dignity jurisprudence. The purpose is not, however, simply to trumpet the virtues of this jurisprudence. The article seeks to address the more critical question as to whether or not this jurisprudence is unduly idealistic. It highlights certain lines of tension which cast a shadow over the ability of Sachs, and his rainbow vision, to slay the dragon of intolerance in South Africa.

\section{ALBIE SACHS AS QUIXOTIC HERO}

The bare bones of Sachs's remarkable career are well-known. He was born in Johannesburg in 1935 and practised as an advocate at the Cape Bar between 1957 and 1966. He was mainly involved in civil rights work, defending those charged under racist apartheid laws and strict security legislation. He was harassed by the security police and was placed under banning orders restricting his movement. He was detained without trial for two extended periods, during which time he was subjected to solitary confinement. As a result of this treatment, in 1966 he opted for political exile in England. He obtained a PhD from the University of Sussex and taught law at the University of Southampton. In 1977 he returned to Africa and became a Professor of Law at the Eduardo Mondlane University in Maputo, Mozambique. In 1988 he was almost killed by a car bomb planted by agents of the apartheid regime, losing his right arm and the sight in one eye. In 1989 he taught at Columbia University in New York and became the founding director of the South African Constitution Studies Centre, based at the Institute of Commonwealth Studies, University of London. In 1992 the Centre moved to the University of the Western Cape, South Africa. As a member of the national executive of the ANC, as well as a member of the ANC's Constitutional Committee, Sachs helped to negotiate South Africa's new constitution. In 1994 he was appointed by Nelson Mandela as a Justice of South Africa's Constitutional Court. He is a prolific author, and one of South Africa's best-loved jurists. In accordance with the provisions of the Constitution, he stepped down as a Constitutional Court judge in October 2009.

Sachs "Preparing Ourselves for Freedom" in De Kok and Press (eds) Spring is Rebellious Arguments About Cultural Freedom by Albie Sachs and Respondents (1990) 19. 
What, however, of the man behind the stark details set out above? A romantic and idealistic thread is apparent throughout both the judgments and other writings of Sachs. Indeed, it is precisely the emotional thrust behind his ideas, his sensitivity to the pain of others, his willingness to dream, and his courage not to allow the dream to die, which has endeared him to lawyers, academics and ordinary South Africans. A good place to start is with his attitude to love. In a paper written to his ANC comrades in 1990, all of whom were still involved in the uncompromising life and death struggle against apartheid, Sachs laments the lack of works, within the revolutionary struggle-art of the time, dealing with the subject matter of love: "And what about love? We have published so many anthologies and journals and
occasional poems and stories, and the number that deal with love do not make
the fingers of a hand. Can it be that once we join the ANC we do not make love
any more, that when the comrades go to bed they discuss the role of the white
working class? Surely even those comrades whose tasks deny them the
opportunity and direct possibilities of love, remember past love and dream of love
to come. What are we fighting for, if not the right to express our humanity in all its
forms, including our sense of fun and capacity for love and tenderness and our
appreciation of the beauty of the world?"

In similar vein, the following words written as he was recovering from the terrible injuries suffered in the notorious apartheid car bomb attack against him in 1988 are, perhaps, representative of his view on women:

"Men talk to you and smile and use words like brave and strong and the struggle, but after shaking my back-to-front hand and sensing relief that the introduction has been so easy, they sit back in their chairs and engage me with words. Women come forward, they hold your arm and nuzzle against your cheek, enabling you to crook your arm around their heads and stroke their hair and feel the tenderness in yourself coming out while you are receiving physical love and comfort from them. The doctors have done their bit, now what I need is endless stroking and warmth."

Perhaps because of the romantic and sensitive side to his nature, Sachs is known for his love of, and involvement with, the world of architecture and art. $\mathrm{He}$ was actively involved "in the development of the Constitutional Court

5 Sachs in De Kok and Press (eds) (1990) 20-21. It is interesting to note that Sachs's paper caused much controversy within the ANC at the time. The Transvaal Interim Cultural Desk of the ANC responded as follows: "We challenge cultural workers to root themselves in the democratic movement so that their creative responses to life will be informed by an understanding and experience of the struggle. We thereby reiterate the view of the Gaberone and CASA (Culture in Another South Africa) conferences on culture that one is first part of the struggle and then a cultural worker." (Transvaal Interim Cultural Desk "The Cultural Boycott and Albie Sachs' Paper" in De Kok and Press (eds) (1990) 107-108.) From this clearly neo-Marxist viewpoint of the relationship between an artist and his or her art, the artist's duty to the "struggle" comes before whatever duty he or she may have to "art". All art is regarded as political, and the artist is not seen as a neutral observer or commentator, but as a political actor engaged in struggle, occupying a particular class position and situated at a particular historical conjuncture. Although this approach may have been necessary and effective at the height of the struggle against apartheid, the question raised by Sachs in his paper was essentially whether or not such an approach would still be desirable in post-apartheid South Africa. As will be argued in the remainder of this article, similar tensions - radical vs liberal, class solidarity vs individual autonomy, rich vs poor, black vs white - continue to bedevil South Africa, a decade and a half after the end of apartheid.

6 Sachs The Soft Vengeance of a Freedom Fighter (1990) 19-20. 
building and its art collection on the site of the Old Fort Prison in Johannesburg". ${ }^{7}$ He was a driving force behind the design of the building and its surrounds, which were deliberately conceptualised as the opposite of a "grand dominant monument". His explanation for this reveals something of the essence of the man and his values:

"Grand dominant monuments are only needed to represent victories of war, exclusivity in the face of threat to an unpopular social system, economic or elite social power, or the unattainable - places of God or the gods. The Constitution, and therefore its houses and precinct, have nothing in common with any of these situations. The Constitution represents the opposite; an alternative means should be found to achieve symbolic importance for the building among the citizens of South Africa. We have chosen to seek the power of a pre-eminent building without the monumentality."

A central concern of Sachs and those responsible for designing the building was that all South Africans, including previously marginalised groups, should feel a sense of ownership and belonging when entering the building. One of the ways in which this was achieved was to call on South Africans from all walks of life to produce works of art which were then incorporated into the very fabric of the building. In the words, once again, of Sachs:

"Like the Constitution, the Court belongs to and serves the whole nation. We want the eyes, hands and hearts of all our artists famous and unknown, to be involved.

We do not want to acquire loose art and place it in the building but rather ensure that the art is integrated into the very fabric of the building. We want this to be a national project.

It is, perhaps, not too far-fetched to state that the South African Constitutional Court building and its art represent not only the spirit of a young democratic South Africa, but also that of Sachs himself.

To conclude this section linking Sachs to quixotic notions of romance and idealism, brief mention may be made of his approach to spirituality. Although he does not appear to subscribe to one or other formal religion, it is clear that he is a deeply spiritual person, and in one of his recent novels he describes himself as "the non-believing Jew, spiritual and dreamy by nature, who believes in belief but has no faith in any supernatural being directing the world". ${ }^{10}$ This deeply spiritual approach to life is reflected in his judgments, and one would be hard pressed to find a more sensitive and insightful description of the importance of spirituality than the following:

"The right to believe or not to believe, and to act or not to act according to his or her beliefs or non-beliefs, is one of the key ingredients of any person's dignity. Yet freedom of religion goes beyond protecting the inviolability of the individual conscience. For many believers, their relationship with God or creation is central to all their activities. It concerns their capacity to relate in an intensely meaningful

See the South African Constitutional Court website: http://www.constitutionalcourt.org.za/site/ judges/justicealbiesachs/index1.html (accessed 2009-09-14).

8 From the Sachs archive: "The Constitutional Court - A New Symbol for Democracy" 8 April 1998; and see Segal (Project Manager) Number Four - The Making of Constitution Hill (2006) 92.

9 Segal 108

10 Sachs (2004) 66. 
fashion to their sense of themselves, their community and their universe. For millions in all walks of life, religion provides support and nurture and a framework for individual and social stability and growth. Religious belief has the capacity to awake concepts of self-worth and human dignity which form the cornerstone of human rights. It affects the believer's view of society and founds the distinction between right and wrong. It expresses itself in the affirmation and continuity of powerful traditions that frequently have an ancient character transcending historical epochs and national boundaries.

Many other examples could be given, but it is submitted that the above adequately demonstrates the romantic, idealistic and, perhaps, quixotic nature of the hero of this article. Attention must now be paid to his specific quest to bring about a rainbow nation at the southern tip of Africa.

\section{TOLERANCE AND THE DIGNITY OF DIFFERENCE - ALBIE SACHS AND THE QUEST FOR A RAINBOW NATION}

In 1990, as South Africa was about to enter the post-apartheid period, Sachs raised a crucial question. South Africans knew what it was to struggle against a brutal regime, but did they know what it meant to be South African? Speaking at an art exhibition in Sweden, he stated as follows:

"You Swedes know who you are. Perhaps your artists have to explore underneath all your certainties, dig away at false consciousness. We South Africans fight against real consciousness, apartheid consciousness, we know what we struggle against. It is there for all the world to see. But we don't know who we ourselves are. What does it mean to be a South African? The artists, more than anyone, can help us discover ourselves. Culture in the broad sense is our vision of ourselves and of our world. This is a huge task facing our writers and dancers and musicians and painters and film-makers. It is something that goes well beyond mobilising people for this or that activity, important though mobilisation might be."

Even though it is now almost twenty years since Sachs called attention to the issue of what it means to be South African, it is submitted that this vital question has not been properly answered. Furthermore, as the rest of this article will attempt to show, it is a question that needs urgently to be answered if South Africa is finally to overcome the legacy of apartheid. Sachs has done more than his fair share in pointing the way to a possible answer, but the question which remains is whether or not his has been a hopelessly idealistic quest, doomed to failure in the face of harsh realities.

During the course of his quest in search of the rainbow nation, and after the fashion of any true quixotic hero, it is submitted that Sachs has marked his journey by making a number of important personal and political transitions along the way. It is important to trace certain of these transitions. He starts out as a dedicated revolutionary, committed to class struggle and fired up by neo-Marxist theory, but ends as a reconciler, who seems much more concerned with the

1 Christian Education South Africa v Minister of Education 20004 SA 757 (CC) par 36.

12 Sachs "Afterword: The Taste of an Avocado Pear" in De Kok and Press (eds) Spring is Rebellious - Arguments About Cultural Freedom by Albie Sachs and Respondents (1990) 146. 
protection of individual autonomy in the liberal sense championed by John Stuart Mill, than with the violent overthrow of the bourgeoisie as predicted by Marx. He starts as a dedicated cadre of the ANC operating at the very highest levels of that organisation, but then is required to relinquish his party membership when he dons the robes of a Justice of the newly formed South African Constitutional Court. It may be somewhat simplistic to describe his journey as being one from Marx to Mill, but something of this simple distinction is reflected in the following passage written by Sachs himself:

"I was engulfed for some years of my life by the philosophy of historical materialism, which, I told myself at the time, was not orthodoxy but science ... Later I came to be a member of the biggest party in the world, the party of excommunists, which is full of bewildered people from every continent. People who had asked the hardest questions of the age and shown the greatest courage in fighting for a world without exploitation ... My concern today with avoiding the imposition of orthodoxies of behaviour or belief by the state influences the way I interpret our Constitution. I have gone further than any of my colleagues in emphasizing that the Constitution calls for the widest recognition of openness, difference and pluralism .... It is easy to tolerate beliefs and practices that are familiar and enjoy strong political support. The true test of tolerance comes when the practices exist on the margins of society and appear bizarre, even threatening to the mainstream.

It seems clear, therefore, that whereas his journey may have started with the emphasis on solidarity and struggle, it ends with a focus on diversity and tolerance - in effect, with his vision of a "rainbow nation". Another way, perhaps, in which to describe this transition, is that it was a move from a position characteristic of a Critical Legal Studies approach to law, which is distrustful of Western liberal rights discourse, to one of a deep commitment to Western style constitutional democracy, with its liberal notions emphasising the importance of individual autonomy and human rights. Sachs reflects this transition as follows:

"At an earlier stage of my life ... I was hostile to a Bill of Rights because it took
out of the political arena issues that were really political in character. I believed it
was far better to allow such matters to be resolved through struggle and
democratic processes than to convert them into juridical questions to be settled
by elite and usually conservative lawyers ... Today I see withdrawing certain
questions from the political arena as being the principal virtue of a Bill of Rights.
Disputes over relatively small issues can induce intense alarm if seen as the thin
end of the wedge for something more significant ... Intense mobilization and
counter-mobilization can take place, and the country can be torn apart over a
matter that has more symbolic than real importance. It is precisely these tinder-
dry, inflammable issues ... that a Bill of Rights can embrace and respond to. It
converts potentially destructive clashes into contained legal disputes, to be
decided by a dedicated body of jurists in a rational manner, according to agreed-
upon processes and internationally accepted principles."

Having discussed certain of the personal and political transitions made by Sachs during the course of his journey, it is important to point out that his ultimate goal, the focus of his quest, has remained remarkably consistent over the years. Even before the end of apartheid, Sachs was clear-sighted in his vision of a rainbow nation, characterised by tolerance and mutual respect

13 Sachs (2004) 67-68.

14 Sachs (2004) 39. 
among and between its citizens. In 1990, as apartheid was coming to an end, he enunciated his vision as follows:

"In rejecting apartheid, we do not envisage a return to a modified form of the British Imperialist notion, we do not plan to build a non-racial yuppie-dom which people may enter only by shedding and suppressing the cultural heritage of their specific community. We will have Zulu South Africans, and Afrikaner South Africans and Indian South Africans and Jewish South Africans and Venda South Africans and Cape Moslem South Africans (I do not refer to the question of terminology - basically people will determine this for themselves). Each cultural tributary contributes towards and increases the majesty of the river of South African-ness. While each one of us has a particularly intimate relationship with one or other cultural matrix, this does not mean that we are locked into a series of cultural 'own affairs' ghettoes. On the contrary, the grandchildren of white immigrants can join in the toyi toyi - even if slightly out of step - or recite the poems of Wally Serote, just as the grandchildren of Dinizulu can read with pride the writings of Olive Schreiner. The dance, the cuisine, the poetry, the dress, the songs and riddles and folk-tales, belong to each group, but also belong to all of us ... Each culture has its strengths, but there is no culture that is worth more than any other. We cannot say that because there are more Xhosa speakers than Tsonga, their culture is better, or because those who hold power today are Afrikaans-speakers, Afrikaans is better or worse than any other language.

The above vision permeates many of the writings and judgments of Sachs. In his book The Soft Vengeance of a Freedom Fighter he tells of being visited in hospital by Jacob Zuma, one of his comrades in the leadership of the ANC at the time, and the current president of South Africa. At that time, Sachs was recovering from the terrible injuries he suffered in a car bomb blast orchestrated by agents of the apartheid regime, and speaks in moving and personal terms of the visit as follows:

"Zuma's African-ness, his Zulu appreciation of conversation and humour is mingling with my Jewish joke, enriching it, prolonging and intensifying the pleasure. We are comrades and we are close, yet we do not have to become like each other, erase our personal tastes and ways of seeing and doing things, but rather contribute our different cultural inputs so as to give more texture to the whole. This is how one day we will rebuild South Africa, not by pushing a steamroller over the national cultures, but by bringing them together, seeing them as the many roots of a single tree, some more substantial than others, but all contributing to the tree's strength and beauty."

It is this dream of a rainbow nation which, years later, Sachs brings to his judgments as a Justice of the Constitutional Court. It is submitted that one of the most moving articulations of his vision is to be found in the well known Constitutional Court judgment of Fourie. ${ }^{17}$ This was the case which resulted in the legalisation of same-sex marriages in South Africa, making it only the fifth

15 Sachs in De Kok and Press (eds) (1990) 25. Elsewhere in the same work he makes a similar point when he states as follows: "We believe in a single South Africa with a single set of governmental institutions, and we work towards a common loyalty and patriotism. Yet this is not to call for a homogenised South Africa made up of identikit citizens. South Africa is now said to be a bilingual country: we envisage it as a multi-lingual country. It will be multi-faith and multicultural as well. The objective is not to create a model culture into which everyone has to assimilate, but to acknowledge and take pride in the cultural variety of our people". Sachs in De Kok and Press (eds) (1990) 24

16 Sachs (1990) 118-119.

17 Minister of Home Affairs v Fourie 20061 SA 524 (CC). 
country in the world, and the first in Africa, to take this step. Sachs wrote the judgment which, apart from a single dissenting judgment on a point not related to the substance of his argument, was unanimously adopted by the Court. There is one paragraph in the judgment which deserves to be quoted at length, since it may be said to represent the noble dream of Sachs:

"A democratic, universalistic, caring and aspirationally egalitarian society embraces everyone and accepts people for who they are. To penalise people for being who and what they are is profoundly disrespectful of the human personality and violatory of equality. Equality means equal concern and respect across difference. It does not presuppose the elimination or suppression of difference. Respect for human rights requires the affirmation of self, not the denial of self. Equality therefore does not imply a levelling or homogenisation of behaviour or extolling one form as supreme, and another as inferior, but an acknowledgement and acceptance of difference. At the very least, it affirms that difference should not be the basis for exclusion, marginalisation and stigma. At best, it celebrates the vitality that difference brings to any society. The issue goes well beyond assumptions of heterosexual exclusivity, a source of contention in the present case. The acknowledgement and acceptance of difference is particularly important in our country where for centuries group membership based on supposed biological characteristics such as skin colour has been the express basis of advantage and disadvantage. South Africans come in all shapes and sizes. The development of an active rather than a purely formal sense of enjoying a common citizenship depends on recognising and accepting people with all their differences, as they are. The Constitution thus acknowledges the variability of human beings (genetic and socio-cultural), affirms the right to be different, and celebrates the diversity of the nation. Accordingly, what is at stake is not simply a question of removing an injustice experienced by a particular section of the community. At issue is a need to affirm the very character of our society as one based on tolerance and mutual respect. The test of tolerance is not how one finds space for people with whom, and practices with which, one feels comfortable, but how one accommodates the expression of what is discomfiting."

It is submitted that the above sets out the ultimate goal of Sachs's lifelong quest. ${ }^{19}$ In the final sections of this article, the extent to which this goal may be

18 Minister of Home Affairs $v$ Fourie supra par 60. Further on in his judgment, in terms which may be said to be distinctly reminiscent of the thinking of John Stuart Mill and Ronald Dworkin, Sachs $\mathrm{J}$ drives home the basic point made in the section quoted, when he states as follows: "The hallmark of an open and democratic society is its capacity to accommodate and manage difference of intensely-held world views and lifestyles in a reasonable and fair manner. The objective of the Constitution is to allow different concepts about the nature of human existence to inhabit the same public realm, and to do so in a manner that is not mutually destructive and that at the same time enables government to function in a way that shows equal concern and respect for all." See Minister of Home Affairs v Fourie supra par 95.

19 Note that it is not only in the judgment quoted that Sachs emphasises the need to be tolerant of difference, particularly in the South African context. It is a central theme in many of his judgments. Eg, in the case of Prince $v$ President of the Law Society, Cape of Good Hope 2002 2 SA 794 (CC) par 170, he states as follows: "Given our dictatorial past in which those in power sought incessantly to command the behaviour, beliefs and taste of all in society, it is no accident that the right to be different has emerged as one of the most treasured aspects of our new constitutional order." In the case of Christian Education South Africa $v$ Minister of Education supra par 23, he states "that if society is to be open and democratic in the fullest sense it needs to be tolerant and accepting of cultural pluralism". He also speaks of the constitutional value of acknowledging diversity and pluralism in our society" and goes on to mention the right of people to be who they are without being forced to subordinate themselves to the cultural and religious norms of others", as well as "the importance of individuals and communities being able to enjoy what has been called the 'right to be different'". (Christian Education South Africa $v$ Minister of Education supra par 24.) In the case of $S v$ Lawrence, $S \vee$ Nagel, $S \vee$ Solberg, he points out that: "What comes through as an innocuous part of daily living to one person who happens to 
said to be realizable will be interrogated, as well as the extent to which Sachs's views may be said to be akin to tilting at windmills. This section will be concluded by quoting again from the writings of Sachs, this time his thoughts on the place of the white racial group in a democratic South Africa. Written in 1990, his words are full of optimism, but he seems acutely aware that beneath the surface of his rainbow vision is a struggle in black and white:

"Whites are not in the struggle to help the blacks win their rights, they (we) are fighting for their own rights, the rights to be free citizens of a free country, and to enjoy and take pride in the culture of the whole country. They are neither liberators of others, nor can their goal be to end up as a despised and despising protected minority. They seek to be ordinary citizens of an ordinary country, proud to be part of South Africa, proud to be part of Africa, proud to be part of the world. Only in certain monastic orders is self-flagellation the means to achieve liberation. For the rest of humankind, there is no successful struggle without a sense of pride and self-affirmation."

Fifteen years into democracy, there are worrying signs that many South Africans of all colours of the rainbow both feel despised by, and in their turn despise others of, this or that particular group of their fellow citizens. It may be argued, perhaps, that the fault lines of race, gender, political affiliation, economic class and sexual orientation, to name but a few, are posing an everincreasing threat to South Africa's rainbow.

\section{SLAYING THE DRAGONS OF RACISM, SEXISM, POVERTY AND XENOPHOBIA - A HOPELESS QUEST?}

The ideal world of tolerance and respect for the "dignity of difference" posited by Sachs in his writings and judgments, may be counterpoised with the real world which is South Africa today. ${ }^{21}$ This is a world in which scores of "foreigners" were brutally murdered in a series of xenophobic attacks perpetrated

inhabit a particular intellectual and spiritual universe, might be communicated as oppressive and exclusionary to another who lives in a different realm of belief. What may be so trifling in the eyes of members of the majority or dominant section of the population as to be invisible, may assume quite large proportions and be eminently real, hurtful and oppressive to those upon whom it impacts. This will especially be the case when what is apparently harmless is experienced by members of the affected group as symptomatic of a wide and pervasive pattern of marginalisation and disadvantage" ( $S$ v Lawrence, S v Nagel, S v Solberg 19974 SA 1176 (CC) par 161).

20 Sachs in De Kok and Press (eds) (1990) 27. At around the same time, in commenting on the fact that, in his opinion, the ANC had been successful in resolving cultural tensions between its members, Sachs stated as follows: "This must be one of the greatest cultural achievements of the ANC, that it has made South Africans of the most diverse origins feel comfortable in its ranks. To say this is not to deny that cultural tensions and dilemmas automatically cease once one joins the organisation: on the contrary, we bring in with us all our complexes and ways of seeing the world, our jealousies and preconceptions. What matters, however, is that we have created a context of struggle, of goals and comradeship within which these tensions can de dealt with" (Sachs in De Kok and Press (eds) (1990) 22-23). This may have applied to those united in struggle, but what is left moot is the manner in which cultural tensions between those inside and those outside the ANC and its traditions were to be resolved during the postapartheid period, once the ANC switched from being a liberation movement involved in a revolutionary struggle, to a political party governing the country as a whole.

21 The term "dignity of difference" has been borrowed from Jonathan Sacks The Dignity of Difference: How to Avoid the Clash of Civilizations (2003). 
throughout the country during 2008. It is a world in which the levels of inequality between rich and poor are amongst the highest in the world. ${ }^{22}$ It is a world in which, in scenes reminiscent of the struggle against apartheid, the poor are increasingly resorting to violent protest against "poor service delivery". ${ }^{23}$ It is a world in which the levels of violence perpetrated against women by men are truly appalling. ${ }^{24}$ Finally, it may be argued, it is a world in which issues of race and racism cast a deep shadow over almost every public debate, subjecting South Africans to a constant barrage of anger and recrimination. It is on this last-mentioned issue that the focus will now fall, since it provides a stark contrast to Sachs's vision of a rainbow nation.

The extent to which racial polarisation and animosity still exist in South Africa, a decade and a half after the end of apartheid, is well illustrated by a series of debates which erupted on the issue of an alleged attempt in May 2008 by Judge John Hlophe, the Judge President of the Cape High Court, to influence certain Justices of the Constitutional Court improperly in a number of matters which involved Mr Jacob Zuma. At that time Mr Jacob Zuma was in the running for the position of President of the Republic of South Africa, and he was subsequently elected to that position. The Justices of the Constitutional Court laid a complaint against Judge Hlophe with the Judicial Services Commission and he laid a counter-complaint against them for allegedly violating his rights by the premature publication of the complaint against him. In August 2009, after a period of protracted legal wrangling, the Commission stated that it did not intend to continue with the investigation of the complaint against Judge Hlophe. A retired white judge of the Constitutional Court, Judge Johann Kriegler, on behalf of an organisation by the name of Freedom Under Law (FUL), then announced that this organisation would seek judicial review of the decision taken by the Judicial Services Commission. This decision by Freedom Under Law (as with many of the decisions taken during this drawn out saga) unleashed a storm of protest, much of it with a strong racial undertone. For example, in an article in

22 According to a recent report in a respected daily newspaper: "South Africa has overtaken Brazil as the country with the widest gap between rich and poor, according to figures put together by a leading South African academic. Haroon Bhorat, an economics professor at UCT, told a briefing at Parliament on Friday that South Africa was now 'the most unequal society in the world' with a significant increase in income inequality ... Bhorat said South Africa's Gini coefficient index which shows the level of income inequality - stood at 0.679" (28 September 2009 The Mercury 13).

23 As long ago as 2004, activists and scholars such as Ashwin Desai and Richard Pithouse were tracing growing levels of resistance within poor communities in South Africa in opposition to perceptions of increasing impoverishment and marginalisation. They submitted that "the rebellions that are breaking out around the country with increasing frequency are almost always fuelled by the exclusion of poor communities from services that they already have and not the failure of the government to "deliver" fast enough" and argued that "the rich are getting richer and the poor are getting poorer, amidst a raging orgy of dispossession and enrichment by primitive accumulation" (Desai and Pithouse "Sanction All Revolts: A Reply to Rebecca Pointer" 200439 Journal of Asian and African Studies 295 297).

24 Eg, according to "AfroAIDSinfo", a web-based information portal developed by the South African Medical Research Council: "Sexual violence against women and girls is a problem of epidemic proportions in South Africa, with child rape as one of its particularly disturbing features." According to the same source: "Police statistics for 2004/2005 reveal that children represented 40,8 percent $(22486)$ of all reported rapes (55 114) in South Africa. 14\% were younger than twelve years." See http://www.afroaidsinfo.org/ShowProperty?nodePath=/BEA\%20Repository/ files/education/sexualviolence.pdf (accessed 2009-10-01). 
the Business Day on 9 September 2009, Sipho Seepe, a higher education and strategy consultant, stated as follows:

"From time to time some among us remind us of our place in the sun. They crack a whip to ensure that we are in line. They see it as their God-given duty to determine not only what we should talk about but also how we should conduct ourselves ... This group would want us to believe that we are hung up and obsessed with the issue of racism. Since racism is an abstract subject to them, their reaction is to denigrate, to caricature as lunatics those who dare raise the subject. Labels such as 'racial nationalists' and 'black chauvinists' are hurled at those who decry racism in our national life. The idea is to intimidate them into silence. And like slaves in the plantation we fall into line ... The tendency to impugn the integrity of those who hold views different from our own is a variation of this master-slave mentality. The masters posit themselves as custodians of wisdom. Judge Johann Kriegler joins a number of those who seem to suffer from this arrogance."

Racial polarization was equally apparent in debates within the mainly white Afrikaans press. For example, in an article on 11 September 2009 in the Afrikaans newspaper Beeld, struggle theologian Nico Smith placed the worrying racial dimension of the debates surrounding the judiciary in South Africa into sharp focus:

"These days almost no conversation between white South Africans takes place without a discussion of the dreadful situation in which the country finds itself. And always it is the black government and all black people that are blamed ... White South Africans will have to consider their presence in Africa in light of what happened to the white French colonists in Algeria ... If they carry on with their opposition to black South Africans and the black government, the day might arrive when the black population simply says: 'Enough is enough. We are tired of constantly being criticized and humiliated by white people'... Should this lead to mass violence against whites, they would be like rats in a trap. They have no motherland to send ships to rescue them. They would have to endure a massacre ... We have got no choice but to become loyal South Africans and to forget about our minority rights, our language and culture, our demands for an end to affirmative action and the return of the death penalty ... If we go on as we are, ten to one we shall move closer to the abyss into which we could plunge ... It is too much to hope that we shall be pulled back from the edge of the abyss for a second time. White South Africans must take action before they are pushed over the edge of the abyss in the same manner as the white colonists in Algeria ..."

The newspaper's editor, Tim du Plessis, responded inter alia as follows to the views of Smith quoted above:

"[T]he great settlement of '94 and the Constitution of '96 do not provide for a regime in which white people travel second class, look at the ground and remain silent. Nothing is said about 'revenge' for apartheid in the sense of punishment. This is also not what the ANC proclaims in its writings or in its speeches, although its body language and sub-text do indicate fairly strongly that white people should rather be thankful and remain quiet ... The remonstrations of [Nico] Smith in particular will inflame emotions. Perhaps it is a good thing that we speak straightforwardly about these issues for once."

\footnotetext{
9 September 2009 Business Day.

11 September 2009 Beeld (author's own translation from the Afrikaans).

27 lbid.
} 
Reflecting the worrisome deterioration of race relations within South Africa during this period, an issue of the respected South African weekly newspaper the Mail \& Guardian was devoted almost entirely to "The Race Issue". ${ }^{28}$ One of the contributors to this issue, Andile Mngxitama, delivered, inter alia, the following sobering indictment of race relations in the post-apartheid period:

"A black grammar of suffering ends dialogue and demands justice. Such grammar locates the creation of blackness at the vortex of three dispossessions: land, labour and the African sense of being. These dispossessions created white wealth and black poverty. Post-1994 sustains this anomaly ... Racism is going nowhere as long as the structures of white supremacy remain intact, covered in the language of democracy and nonracialism ... The end of racism depends on what blacks do and has little to do with whites. Right now blacks lack a grammar of black suffering and that's the problem."

An article by Njabulo $S$ Ndebele in the same issue of the Mail \& Guardian, struck a more conciliatory tone. Entitled "Of Pretence and Protest", the subtitle of the article provides one with a feel for the essence of the debate, indicating clearly the writer's belief that South Africa today is far from a rainbow nation characterised by tolerance and respect for difference, as envisaged in the writings and judgments of Sachs. ${ }^{30}$ The subtitle reads: "The collective anguish of a nation trying to find the way past race and into leadership." Ndebele begins with the following quote from a previous Mail \& Guardian article by David Smith, in which Smith speaks of the pretences of both white and black South Africans: "The whites are pretending it didn't happen; the blacks are pretending to forgive. ${ }^{, 31}$ Ndebele views these pretences as coping mechanisms adopted by both white and black South Africans to get by in present day South Africa, and calls for leadership which will "place the shared anguish of coping through pretence within the realm of responsibility" and "use it as a basis for a sensitive attempt to create ever-expanding circles of social solidarity across the great barriers of race, ethnicity, gender and class without fudging their impact., ${ }^{32}$ Ndebele further calls for a commitment "to finding an appropriate political instrument that will set a foundation of trust for South Africans to recover their shared idealism" and points out that "[t]his demands that we reconnect with the founding compromises of the negotiated settlement that led to 1994., ${ }^{, 33} \mathrm{He}$ concludes his article by calling on South Africans to "recommit to diversity in solidarity, collaboration, trust, accountability and civility, all of which have a binding effect that should allow us to be aware of barriers that could be permissive or inhibitive, but to learn to think and feel beyond them and across time. ${ }^{34}$

Although many other examples could be cited, those outlined above should provide sufficient evidence of the fractured and traumatised nature of South Africa's collective national psyche at this point in the nation's history. It is

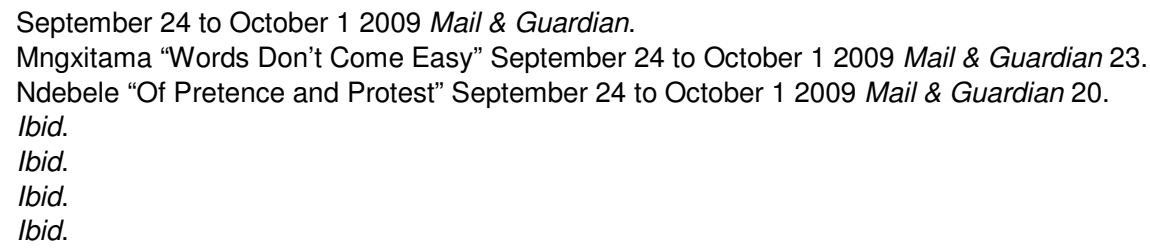


interesting to note that Ndebele in particular points to the need for some sort of reconciliation to take the nation beyond its present state of guilt, fear, anger and recrimination. He does not spell out in sufficient detail, however, precisely how South Africans are to find their way past their present collective anguish, concealed behind the pretence of normality. In the concluding section of this article, it is suggested that the approach adopted by Sachs towards issues of dignity, identity and belonging in post apartheid South Africa may, if properly understood, provide the sort of foundation which will allow South Africans to begin to move beyond the present impasse. In other words, it is submitted that the question which was posed at the outset of this article, may be answered by suggesting that Sachs is more than a Don Quixote tilting at windmills, and that his ideas are in fact a real source of hope. That said, it seems clear that the quest for a rainbow nation is far from over, and will have to be taken forward by equally courageous thinkers and jurists in the future.

\section{$5 \quad$ CONCLUSION - THE QUEST CONTINUES}

Sachs seems to embody, in both his life and in his life's work, a reconciliation between worlds which, more often than not, seemed set to collide rather than synthesise. He has moved, successfully it may be argued, between noble dream and harsh reality; between committed struggle hero and impartial judge; between an absolute commitment to the solidarity of struggle and an equally absolute commitment to individual autonomy and the dignity of difference; between Critical Legal Studies and Liberal Democracy; between Marx and Mill. His dignity jurisprudence, in particular, has made a real difference. South Africans may not yet be ready to embrace his vision, and it may only be a starting point, but he has set the tone.

Finally, it is submitted that the work of Sachs points to a potential synthesis between two great philosophical strands of thought, the one originating in Africa and the other in Western Europe, each having its own profound implications for the dignity and wellbeing of individuals and communities. The one strand is the African concept of ubuntu, linking the individual to the community by focusing on deep bonds of common humanity. ${ }^{35}$ The other strand is the Western liberal conception of the autonomous individual, which holds sacred each particular hope and dream, refusing to allow the particular to be sacrificed completely to

35 It would seem that the concept of ubuntu is, at present, contested terrain. During recent years it has been subjected to a variety of formulations. There are some who maintain that attempts to define the concept too closely are, in fact, harmful to the concept itself. At the risk of greatly oversimplifying a complex issue, it may be worth noting the following extract from the well known Constitutional Court Case of $S v$ Makwanyane, which resulted in the outlawing of the death penalty in South Africa, and in which Mokgoro J stated as follows: "Generally, ubuntu translates as humaneness. In its most fundamental sense it translates as personhood and morality. Metaphorically, it expresses itself in umuntu ngumuntu ngabantu [a person is a person because of other people], describing the significance of group solidarity on survival issues so central to the survival of communities. While it envelops the key values of group solidarity, compassion, respect, human dignity, conformity to basic norms and collective unity, in its fundamental sense it denotes humanity and morality" (see S v Makwanyane 19953 SA 391 (CC) 308) 
the general. ${ }^{36}$ Reconciliation between these two strands of thought may not be easy. Africans have good reason to be suspicious of Western ideas. In the same way that colonialism raped the African continent and sought to rob Africans of their identity, there is deep concern among certain African intellectuals that the concept of ubuntu will be appropriated, co-opted and eventually strangled by the totalising discourse of Western philosophy. Viewed from this perspective, it is not difficult to understand the ideological gulf which could develop between an evolving African philosophy based upon the concept of ubuntu on the one hand, and the notion of constitutional democracy, viewed in the context of its Western liberal roots, on the other. It is at this point, perhaps, that the life and work of Sachs may serve to put us on the path to true reconciliation and harmony.

36 The philosopher Grayling, for example, argues against the notion that the interests of an individual may legitimately be sacrificed for the good of the community, without the consent of the individual concerned. Citing Enlightenment thinkers as diverse as David Hume, Adam Smith, Edmund Burke and William Hazlitt, he points out that "they all refused to allow the particular to be so subordinated to the general that it vanished from view" and explains further as follows: "By this I mean that they saw, in true Enlightenment spirit, that the good life is an individual thing, even though it is lived in community; for the community cannot itself be good cannot constitute the Good Society - unless each of its members is living a life he or she finds satisfying and flourishing both from the individual's own point of view and from the point of view of relationships with others. The general good is thus a function of many individual good lives; and these latter cannot be sacrificed without reducing the good of all. And arguably, if the interests, the hopes - and certainly if the life - of a single individual is sacrificed unfairly or against the individual's will, the general good is diminished thereby; not only by the loss of what is sacrificed, but by the fact that it happened at all" (Grayling The Heart of Things - Applying Philosophy to the $21^{\text {st }}$ Century (2006) 159.) Furthermore, John Stuart Mill, in his well-known Essay on Liberty of 1859, provides the following classic formulation of the general principle: "[T] he sole end for which mankind are warranted, individually or collectively in interfering with the liberty of action of any of their number, is self-protection ... [T] he only purpose for which power can be rightfully exercised over any member of a civilized community, against his will, is to prevent harm to others. His own good, either physical or moral, is not a sufficient warrant" (Mill On Liberty (1859) Chapter 1 par 9). 